\title{
Independence and Interdependence
}

"If any man is excusable for deserting his country," wrote James Fenimore Cooper in his travelogue Gleanings from Europe, "it is the American artist." "His studies require it," Cooper continued, "for there is little to gratify his tastes at home." Yet Cooper conceded that residence abroad was fraught with dilemmas. "The American who comes to this country" and is "forgetful of self-respect, of national pride, of the usages of society even, becomes the toad-eater of the great." ${ }^{2}$ The dilemma of the American in Britain, Cooper argued, reflected the nation's relationship with its former imperial master. Of all the "burthens" [sic] of the nascent American nation, "the mental dependence created by colonial subserviency" is "the most difficult to remove." "We must make up our minds, I fear," Cooper wrote elsewhere, "to live our time as inhabitants of a mere colony." 4

With John Bull intruding into almost every realm of public life in the young republic, the true meaning and extent of independence was unclear. Postcolonial insecurities made the maritime connections of the Atlantic world suspect. "Every shipment, every consignment, every commission," wrote James Madison in a conspiratorial analysis of the United States' Atlantic connections in I799, was "a channel” through which Britain's “Anglicizing” influence flowed. "Our sea-port towns are the reservoirs into which it is collected. From these, issue a thousand streams to the inland towns, and country stores," Madison continued, that allowed a "stock of British ideas and sentiments proper to be 
retailed to the people. Thus it is, that our country is penetrated to its remotest corners with a foreign poison vitiating the American sentiment, recolonizing the American character, and duping us into the politics of a foreign nation." ${ }^{5}$ But ideological warnings alone would not help the United States navigate the fluid context of Atlantic political economy from which Americans made repeated declarations of independence. ${ }^{6}$ Economically, Americans hoped to throw off the chains of their chief creditor and wean domestic consumers off British imports; culturally, American intellectuals struggled to overcome the derivativeness of American morals, literature, and culture. ${ }^{7}$ Those seeking to sever the remaining ties that bound the new nation to the Old World could not escape the interdependence of the British Empire and the United States. As Henry Clay quipped ruefully in I 820 , the United States were little more than the "independent colonies of England." 8 Recognizing the ongoing tension between decolonization and nation-building in Americans' interactions with the wider world, historians have strikingly reframed the antebellum era as "America's postcolonial period."

Britain's own relationship with the Atlantic underwent a dramatic transformation of its own in the decades following the American revolution. The world wars of I793-I8I5 and Britain's industrial revolution opened new colonial markets to British merchants who traded more widely than ever before, thanks to the abundance of credit in London. Over time, Britain dismantled the complex system of protections and privileges known as "mercantilism" and, in I846, switched to international free trade. This commercial and industrial revolution created new demands for a variety of raw materials produced in the Americas, drawing the United States further into the orbit of Britain's imperial economy; so far, according to the historian A. G. Hopkins, that the United States became an "honorary dominion" of the British Empire. ${ }^{10}$ The United States stood to benefit from these transformations-if its leaders could successfully balance the political imperative of securing independence and the nation's continued interdependence with the economic ascendance of the British Empire. ${ }^{11}$ For the aspirational states of the New World, Eliga Gould reminds us, "independent nationhood was an interdependent condition." 12 The constant interplay between the demands of independence and interdependence was the central dynamic of the fragile republic's relationship with the Atlantic world, and to the patterns of American emigration examined in this chapter.

The history of the Atlantic world is the history of human crossings and connection. ${ }^{13}$ Though we tend to think of this travel as westerly, 
eastward-crossing migrants created connections that bound the British Atlantic into a thriving community. Georgian London was the "Capital of America" and a magnet for mobile agents of the Crown, merchant apprentices, aspirational authors and artists, pious pastors, and improvident tourists who enthusiastically embraced metropolitan fashions. ${ }^{14}$ By the eve of the Revolution, these patterns of mobility were powerful agents of Atlantic integration, so much so that the Revolution might be viewed best as a crisis over the pace and style of Atlantic integration rather than the outcome of widening differences. ${ }^{15}$ The Atlantic world's age of revolution dramatically transformed these flows as liberty's exiles took to the oceans-North American Loyalists and fugitive slaves, Irish radicals escaping Britain's "Church and King" repression, French democratic republicans fleeing the terror, and Haitian exiles, free and unfree, were alike set in motion, often in sagas of recurring flight. ${ }^{16} \mathrm{~A}$ burst of transatlantic migration followed the rapid demise of the indentured servant trade, too, as some 252,300 people left the Old World for the New between I776 and I800. ${ }^{17}$

As the nineteenth century dawned, then, the Atlantic was alive with the movement of people. American emigrants tend to get lost amidst these mass migrations because historians over-emphasize the insular quality of the new republic. "It takes many chords to draw such a multitude so far across the ocean," suggested one antebellum writer surveying American tourism, and this chapter begins with a panoramic view of the chords of migration that underlay the political economy of Atlantic interdependence. ${ }^{18}$ The fracturing of the Atlantic community into two political entities in $\mathrm{I}_{7} 83$ had little impact on the eastward movement of people. Migration resumed with remarkable speed after the Peace Treaty, as newly-made Americans rushed eastwards to "knit together the arteries slashed through by war and separation." 19 Transatlantic connections proved not only strikingly persistent, but grew in importance. Americans travelled to Britain for diverse reasons, but did not merely connect points on the map: they directed the transfers of goods, capital, and knowledge that embedded the United States in the Atlantic world. Tourists, preachers, sailors, diplomats, freed and fugitive slaves, reformers, artists, and authors participated in a series of exchanges-of a shared transatlantic travel culture, of religious and moral ideas, of expertise, of economic knowledge, and (as we will see in later chapters) of American businesses-that did not always overlap, but together contributed to Atlantic interdependence.

By I86I, Atlantic crossings were so extensive that the British census captured more than eight thousand American-born residents in the 
country-equivalent to one-third of US citizens travelling overseas at the time, but a simplistic snapshot of the patterns of Atlantic mobility of which they were a part. ${ }^{20}$ Many of those recorded in the census were passing through Britain on larger itineraries that took them to Europe and North Africa, or were temporarily in British port cities as laborers in the Atlantic's maritime industries. Their mobility is reflected in their tendency to cluster in Liverpool and London, together home to half of the American-born in Great Britain: 2,800 in Liverpool and its surrounding counties, and I,9IO in London (an increase from I,O54 in I $85 \mathrm{I}){ }^{21}$ This American presence left its mark on the urban space of both cities, in the hotels, boarding houses, consulates, and social clubs that catered to American migrants and travelers. Amidst these mobile crowds, distinct American communities organized around trade and finance thrived. The final sections of the chapter sharpen focus from the panoramic view of Atlantic crossings to examine Liverpool's emigrant merchants and London's emigrant financiers.

Few British cities could match Liverpool and London for commercial and financial opportunities. As the emporium of transatlantic trade and the port of arrival for American visitors to Europe, Liverpool was the gateway of the United States' Atlantic connections. "London and New York stand in the same rank as Liverpool, as commercial cities," argued one journalist, "but in some respects, as a place of commerce, [Liverpool] surpasses even the great capitals of the Old and New World." 22 By I 800 , Anglo-American merchants benefitted from the "demise of distance," a virtual collapse of time and space achieved by the introduction and spread of commercial newspapers, and from the infrastructure of banks, clearinghouses, insurance companies, and stock exchanges created in the eighteenth century. ${ }^{23}$ All this dramatically altered the speed of information exchange, but was no substitute for human mobility. Posting a partner overseas remained the most effective way of gathering trustworthy information on market opportunities, prices, and creditworthiness-essential to the production of the knowledge economy on which transatlantic markets depended. This arrangement had been the organizing principle of trade in the pre-revolutionary Atlantic and continued to be so throughout the antebellum period, especially as the volume of trade and the demand for economic knowledge increased and partnerships began to specialize in specific commodities such as metals and cotton. ${ }^{24}$ The letter, then, was the paper technology of transnational connection and integral to the material infrastructure of the expanding Atlantic economy. Until I 866, when the Atlantic cable was permanently 
laid, Edmund Burke's I 796 observation that the "correspondence of the moneyed and mercantile world' was a "kind of electric communication everywhere" remained true. ${ }^{25}$

Even after London ceased to be the "capital of America," it continued to be the capital of American credit. As one contemporary description put it, there was "scarcely a commercial transaction upon the face of the globe which is not more or less connected with, or represented by, London." 26 American merchant bankers migrated to Britain to be close to the financial instruments and commodity markets of the City of London, where they maintained the credit network that supported Anglo-American merchants, wholesalers, and producers, and marketed American state debt and railroad securities to credit-rich British investors. Although the economic interdependence created by this vast web of credit and commerce raised the specter of commercial slavery to many Americans, Britons recognized that interdependence was a two-way street. "The prosperity of the United States is so intricately interwoven with that of this country," opined The Times in I $85 \mathrm{I}$, that "for all practical purposes" it was "far more closely united with this kingdom than any one of our colonies." ${ }^{27}$ Transnational currents and capitalist markets did not occur naturally; they required continual maintenance and management to thrive. The daily, and at times routine, work undertaken by emigrant financiers and merchants was essential to transnational connection. Throughout their residence in Britain, American emigrants navigated the "post-colonial predicament" of establishing the balance between independence and interdependence-the central dynamic of this chapter. ${ }^{28}$

\section{AMERICANS WITHOUT NUMBER}

Voyaging twenty days or more across the Atlantic, venturesome Americans had little else to do than travel in their imaginations to a romanticized Britain. On arrival, many were shocked instead at Liverpool's similarity to the United States. ${ }^{29}$ "Liverpool in some respects appears more like an American city than any which I have previously seen," noted the Reverend John March of Salem at the start of his English tour. "This is owing in part to its being more modern," he wrote in his diary, "having commenced its existence about the same time as New York and in part to its important intercourse with America." ${ }^{30}$ Benjamin Silliman, on his second trip to Britain after having studied at Edinburgh University in I 805 , was likewise struck by the incredible likeness of the city's residents to "our own countrymen in our large cities." "Every body here 
talks, dresses and acts, and every thing looks, so much like America," he continued, "I can hardly believe I crossed the ocean." 31 For many, the disappointment was palpable. Arriving in the late I820s, Nathaniel Wheaton found the city no more than "docks, fat men and fat women, coal-smoke, dirty streets, cast iron, mammon and mud." ${ }^{32}$ To another, it was "dark, dingy, and mold-colored." ${ }^{33}$ Harriet Beecher Stowe was crestfallen at finding the port a "real New Yorkish place." 34

The evangelist, the student, the tourist, and the author: March, Silliman, Wheaton, and Stowe highlight the diversity of American travel experiences in the antebellum period but also its striking continuities with the colonial era. All four travelled to Britain along timeworn pre-revolutionary itineraries; all viewed Britain as anxious post-colonials, measuring the imagined refinement of the Old World against the crudity of the New (the "New Yorkish place") they found on arrival; and by crossing the ocean in search of careers and personal objectives, all four reveal the complexity of connection that underlay the interdependence of the Atlantic. They were just the tip of the iceberg. Networks of kinship and friendship, international trade, evangelicalism and reform, fugitive activism, maritime labor, and return migration crossed the ocean in dizzying array. But while for many Americans Atlantic crossings promoted profitable exchanges, for others they were the conduit of dangerous foreign imports.

With the conclusion of the revolutionary wars, the wide web of cultural, familial, religious, and other informal ties that knitted the Atlantic world together proved their resilience. Travel from the United States to Britain quickly resumed. ${ }^{35}$ According to one estimate, between the I8I 8 inauguration of the Black Ball Line, the first transatlantic packet, and I 850 , two to eight thousand Americans ventured to Europe each year. ${ }^{36}$ As early as 1833 , the stream of American visitors to Britain was so large that one American resident in London noted there were "Americans without number." ${ }^{37}$ In the colonial period, elite Americans cultivated refined sensibilities, social standing, and transatlantic professional connections through travel. The colonial Grand Tour became the tourist trail of the I830s, sparking the decade-long boom in Anglo-American travel writing. ${ }^{38}$ American tourists followed well-trodden pathways around the cultural shrines and imperial monuments of the British Isles, where they found "much to admire and imitate." ${ }^{39}$ After this, they took in the sites of antiquity in Rome, the world of Parisian fashion, and the romantic, natural sublime in Northern Europe. During the early years of the republic, Americans also crossed the ocean to restore pre-revolutionary professional and intellectual networks and to acquire specialized training and 
intellectual prestige unattainable in the newly-independent United States. ${ }^{40}$ Artists trained in the studios that orbited the Court of St James; ambitious lawyers at the Inns of Court; and medical students, like Benjamin Silliman, in the anatomical theaters of the University of Edinburgh. ${ }^{41}$ American authors travelled to Britain in search of inspiration and cultural refinement, even while they attempted to unburden the United States from the dominance of its literary models. ${ }^{42}$

By the 1840 , the increased affordability of the Atlantic crossing transformed the demographics of travel. Those traveling under sail could expect to spend between $\$ I_{2} 0$ and $\$ I_{5} 5$ (roughly $\$ 2,500-\$ 3,000$ today) each way for a cabin in the I820s and I830s, a portion of which covered the cost of food and wine, but by 1855 some fares had fallen to $\$ 75$. Steam prices declined similarly between the late 1830 , when they were as high as \$I40, and the I860s when they averaged closer to \$IOO; still, at this time a needlewoman working full-time could at best make \$9I per year. ${ }^{43}$ Not only was a ticket now affordable to more of the "middling sorts," close to one-third of transatlantic passengers were women. ${ }^{44}$ AngloAmerican marriages peaked later in the century, though by 1836 one American correspondent in London reported "great numbers of American ladies in London" who "seemed to be a good deal in fashion." 45 Socially, these women were important points of inter-elite contact and, for diplomatic wives managing the chief American household overseas, integral to the social world of foreign relations, as discussed in the next chapter. Antebellum women's overseas travel did not attract the same ire that it would after the Civil War, but it was considered dangerous to expose young women to the "temptations of the capitals of Europe." ${ }^{46}$ For nationalist Americans, such exchanges indicated a "humiliating deference" and "slavishness" to-or, as Cooper would have it, a "mental dependence" onBritish cultural authority. ${ }^{47}$

The ocean was no barrier to the "ferment of reform" that gripped the Atlantic world in the antebellum period..$^{48}$ Independence did not sever the Protestant bonds created by Empire. ${ }^{49}$ New revivalists and American evangelicals swelled the flow of transatlantic traffic, moving back and forth across the Atlantic, promoting international cooperation, spreading knowledge of the "New-Measures" revivalism fueling fervent evangelical awakenings across the United States among British congregants. ${ }^{50}$ American social reformers integrated easily into British evangelical and reform networks, collaborating in what one historian has called "the Anglo-American world of humanitarian endeavour." ${ }^{51}$ Energetic Britons and Americans successfully fused moral and social reform 
networks-on issues as varied as temperance, abolition, mental health, women's rights, and prisons-with longstanding religious connections, sharing the conception that sin lay at the heart of social problems. ${ }^{52}$ Transatlantic cooperation flourished through the mass circulation of correspondence, journals, pamphlets, and speaking tours and through tangible tactical ties forged by male and female activists at international gatherings such as the World's Anti-Slavery Convention in London in I 840 and the World Temperance Convention in $1846 . .^{53}$ In the same year, more than nine hundred evangelical churchmen from fifty denominations gathered in London for the Evangelical Alliance, the "climax to decades of increasing cooperation across the ocean" between AngloAmerican religious, philanthropic, and reform movements. ${ }^{54}$ This variety of reform connections laid the foundations for transatlantic social politics in the late nineteenth century, but, as revealed in later chapters, they also became key auxiliaries of Civil War diplomacy. ${ }^{55}$

Britain beckoned as a safe haven for American abolitionists under attack at home as dangerous foreign agents. ${ }^{56}$ After West Indian emancipation in 1833 , Britain not only projected great symbolic and ethical power across the Atlantic, but among African Americans especially, was prized as an avenue of escape and empowerment. ${ }^{57}$ For some the move was permanent, for most a sojourn on a journey to spread liberty around the Atlantic world. Scholars of black culture have established the centrality of transatlantic mobility to black identity and political consciousness, characterizing it as the central process underpinning the transcultural production of the black Atlantic. ${ }^{58}$ Reflecting on their own mobility as a "liberating respatialization" of the Atlantic, black activists extended their own political agency by harnessing the power of British imperial abolitionism against the Southern empire of slavery. ${ }^{59}$ "I am here, because you have an influence on America that no other nation can have," Frederick Douglass told congregants at Finsbury Chapel in I846, explaining that "the power I extend now is something like the power that is exerted by the man at the end of the lever; my influence now is just in proportion to the distance that I am from the United States." ${ }^{60}$ Such processes are better viewed as integral to the ongoing debate over Atlantic interdependence than they are as an exercise in counter-networking, then. Still, completing the transatlantic crossing was an emotive, even "talismanic" moment for black travelers. ${ }^{61}$ In April I 840, Charles Lennox Remond, a free black from Salem, Massachusetts, sat in a drawing room in Newport, Rhode Island, and recorded his great anticipation of crossing the Atlantic to "tread upon the soil 
which the poor slave has but to touch and become free" and "inhale the air which if the slave shall breathe his shackles fall off." 62

Fugitives fled to Britain in great numbers after the passage of Fugitive Slave Act of 1850 , which abolished habeas corpus and Fourth Amendment protections for free blacks. Once in Britain they lectured and performed in taverns, church halls, theaters, and private parlors, exploiting the new republic's vulnerability to international public opinion. Such trips were highly organized and efficient. Frederick Douglass alone gave three hundred speeches in just nineteen months between I 845 and I $847 .^{63}$ British audiences were deeply engaged in the anti-slavery struggle-Uncle Tom's Cabin sold perhaps more than half a million copies (mostly pirated) in Britain and its colonies in I853-and were energized further by the performative aspects of the transatlantic campaign: some speakers included panoramas depicting the horrors of enslavement and others used theatrical processions through local towns, such as Henry "Box" Brown's dramatic re-staging of his own escape. ${ }^{64}$ The Mother Country's moral capital hid sobering realities-Britain was scarcely a haven from racism-but few areas of the country went untouched by the lecture tours of black abolitionists, supported by slave narratives, autobiographies, and pamphlets. Almost every major black antebellum leader visited Britain as an emissary, managing the movement's relationship with British abolition and overseeing a "new phase of international cooperation" that gave the period's black radical identity a transnational quality ${ }^{65}$ Such action had direct domestic consequences. "Every steam-ship that now crosses the Atlantic is an Anti-Slavery packet, and comes here freighted with intelligence which serves to advance the cause of freedom," declared the delegates at one convention in Worcester, Massachusetts. ${ }^{66}$

The mobility of people of color in the Atlantic world posed challenging questions about the racial boundaries of Atlantic connection. Nowhere was this more the case than with merchant seamen. ${ }^{67}$ Sailors kept the Atlantic economy afloat; an estimated I00,000, of whom one-fifth were African American, departed the republic each year during the antebellum era and have been called the nation's "international face." " But while white working-class seamen were valued as conduits of "knowledge" about foreign societies-and as often vilified by exasperated consuls for their violent encounters with the peoples in those places-their general right to sail was not questioned. This cannot be said of dangerously mobile free black seafarers. Southern lawmakers and editorialists feared the "moral pestilence" of free black mariners who were an "evil which comes from a distance" and embodied a subversion of the social order that 
threatened to destroy slavery's containment of black mobility. ${ }^{69}$ Infectious abolitionism travelled Atlantic waters, claimed anxious Southerners in the wake of the Denmark Vesey conspiracy, resulting in the passage of Negro Seamen Acts to quarantine subversive black deckhands from gullible local slaves in southern seaports-first in South Carolina but quickly followed by North Carolina, Georgia, Florida, Alabama, Louisiana and Texas-by subjecting all black mariners, regardless of nationality, to imprisonment under threat of enslavement. ${ }^{70}$ As the historian Edlie Wong has forcefully written, outlawing black freedom of movement was elemental to the "territorialization of freedom in the Atlantic world" and "part of the systematic containment of the physical, social, and political dimensions of black mobility that was fundamental to the logic of mastery." ${ }^{\prime 11}$ Laws against black sailors were thus fundamentally about the threats of transnational interconnection and aimed not merely to prevent slave insurrection but to regulate a much greater menace: the black Atlantic.

Integral to the nineteenth-century black Atlantic was the "geography of freedom" created by British abolition. ${ }^{72}$ Canada, the British West Indies, and the British Isles all provided maritime escape routes from servitude-if escapees could navigate these unpredictable waters. ${ }^{73}$ Black American sailors jumped ship or discharged their berths on landing in Liverpool, Bristol, London, and Glasgow, havens of a sort for the diaspora of the black Atlantic world. ${ }^{74}$ "In Liverpool," wrote the mariner-turned-novelist Herman Melville, "the negro steps with a prouder pace and lifts his head like a man; for here, no such exaggerated feeling exists in respect to him, as in America." Black sailors, stewards, sailmakers, and stevedores, Melville continued, enjoyed "unwonted immunities" in the port and were, therefore, "very much attracted to the place and like to make voyages to it." 75 In the dockside area of Toxteth, African Americans entered one of Britain's oldest black communities, composed of fugitive slaves, African traders, Caribbean seafarers, and discharged sailors and soldiers who worked in the port's booming maritime industries. ${ }^{76}$

The "hub" of the black Atlantic was London. ${ }^{77}$ From the 1780 s, the

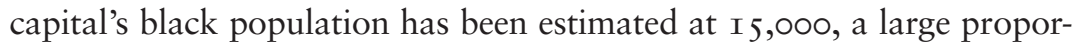
tion of whom were recent arrivals from North American or West Indian colonies, many moving on to other locales in the Empire. ${ }^{78}$ Britain, then, "served more as a crossroads for black people in the Empire and elsewhere rather than a site of permanent settlement," writes the historian Winston James of the nineteenth century. ${ }^{79}$ Most arrived on trading winds. Merchants and sailors from the Gold and Windward Coasts and Kru, with a long heritage of seafaring from West Africa, were joined by 
East Indian "lascars," servants of the East India Company, who numbered I, 336 by I 8 I $3 .{ }^{80}$ London's black populations "integrated with considerable success" in the East End, where racial mixing was no longer exceptional. ${ }^{81}$ Communities in the riverside slums of Wapping (where the London Dock Company and Tobacco Dock were situated), Shadwell, Poplar (home to the West India docks), Canning Town (housing the Royal Docks), Rotherhithe (where American trade docked at the East Country Dock, renamed the South Dock in I 850 ), and Limehouse (where cargoes were offloaded onto canal barges at the Regent's Canal Dock) were composed largely of transient seafarers, living in sailors' boarding houses before taking return berths to the Gold Coast or West Indies. ${ }^{82}$ Along the West India Dock Road, the Stranger's Home for Asiatics, Africans and South Sea Islanders opened in I 857 to cater to these transient populations. ${ }^{83}$ To the northwest in St Giles, London's blacks mixed freely with other immigrant groups (see figure 5). Cable Street, for instance, was the site of "common lodging houses occupied by English, Scotch, Irish, Welsh, Americans, Germans, Norwegians, Flemish, Chinese, West Indians, and others." ${ }^{84}$ African Americans joined this diverse black community and were prominent in these dockside areas, as shipping remained one of the few expanding industries open to men of color. ${ }^{85}$

But docksides were not exactly the racial refuges depicted by Melville or imagined by many African Americans-and sometimes suffered from the importation of US problems that British observers took to be a sign of the moral contagion spread by American slavery, a striking reversal of Southern fears of mobile African Americans. In some ports, American ships were anchored for up to a month, giving sailors plenty of time ashore. In I 820 one French traveler recorded two hundred American vessels anchored at Liverpool's docks, along with which came a flood of American tars to the boarding houses and taverns that lined the port's wharves. ${ }^{86}$ Often paid at the end of the trip, many seamen squandered their wages carousing onshore between voyages. In Liverpool, white American sailors were frequently hauled before the local magistrate after acts of racial violence. ${ }^{87}$ In 1858 , an American seaman named George Washington Dickson shot a black Liverpudlian in the arm, chest, and thigh, in what Dickson described as a "muss" on the street. ${ }^{88}$ In a separate incident, two American sailors, "excited by the dark skin of their victims," beat a Hindu tract seller about the head in "a most dastardly manner," assaulted a passing black sailor, and beat the mother of a mixed-race child. The judge overseeing the case hoped that a $£_{5}$ fine-equivalent to two and a half month's wages-for assault would 


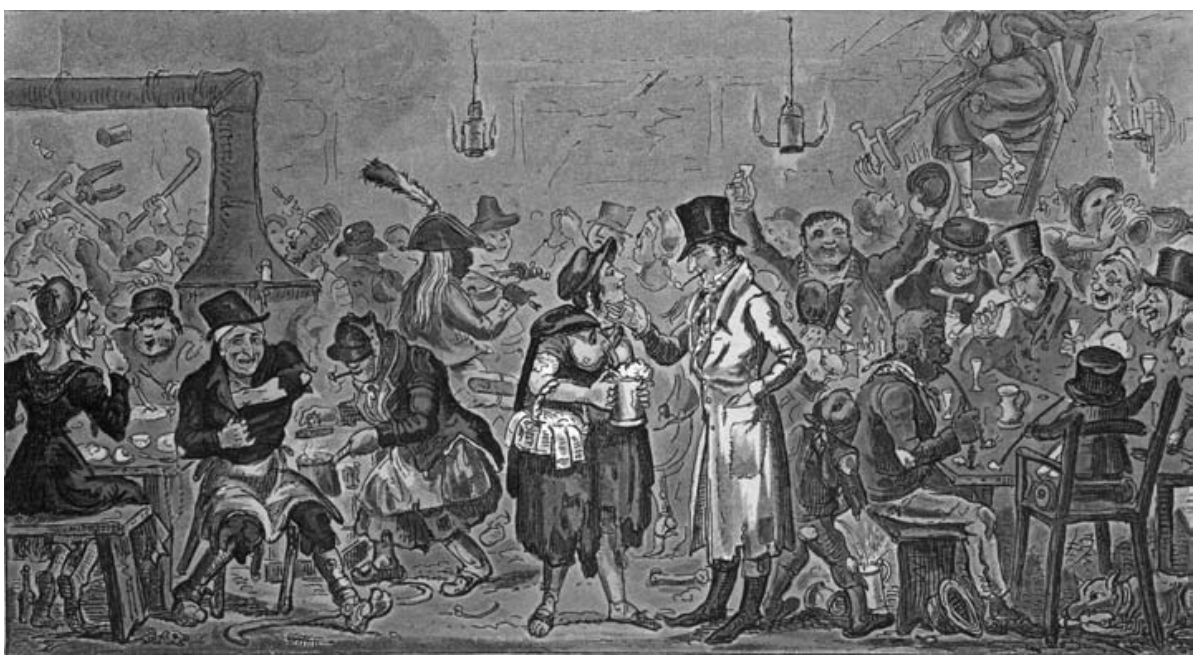

FIGURE 5. In this rare depiction of life in East London, brothers Isaac Richard and George Cruickshank depict black sailors and entertainers mixing with other poor drinkers in the "Holy Land," a slum in the district of St Giles, so-called because of the large number of Irish Catholic migrants in the area. Accounts of the "black poor" were part observation, part reification of the Georgian and Victorian racial imaginary. It was no coincidence that images of black mendicants presenting themselves with fawning propriety on the streets of London, as found in Henry Mayhew's three-volume London Labour and the London Poor (I85I), and the exaggerations of black minstrelsy based in the theaters of Drury Lane and the Vauxhall Pleasure Gardens, were popularized as Anglo-Saxon racial ideologies took hold in Victorian Britain (Lorimer, Colour, Class, and the Victorians, 86; Dubrulle, "Britain, the Civil War, and Race"). Image: "Tom and Jerry 'Masquerading it' among the cadgers in the 'Black Slums' of the Holy Land," Peirce Egan, Life in London (London: John Camden Hotton, I 823), (c) British Library Board. All Rights Reserved / Bridgeman Images.

"convince such of our American visitors as venture to beat and kick a man because he has black skin, that the law is too strong for them." While "in general the American sailors are well behaved and as respectable as our own," he continued, "now and then ... the curse which slavery brings appears." 89

Life in Britain was precarious for those who raised the capital and courage to seek asylum across the Atlantic. William G. Allen expatriated himself to Britain in the late 185 os, but failed to prosper outside of the lecture circuit. In May I 859 he wrote home to Gerrit Smith that he was "in the midst of a desperate struggle with the wolves, who are trying to break in at the door." ${ }^{90}$ In response, fugitives in London organized the short-lived association American Fugitive Slaves in the British Metropolis to help the destitute and were soon joined by the Ladies Society for the 
Aid of Fugitive Slaves in England. ${ }^{91}$ Not all fugitives became destitute. Some, like Moses Roper and Alexander Crummell, successfully enrolled as students with funding from philanthropic networks, while others found employment as footmen, coachmen, street sweepers, or army bandsmen. ${ }^{92}$ Still, the dream of independence was difficult to realize for black migrants who found their access to already meager resources squeezed by increasing numbers of transatlantic migrants fleeing the Fugitive Slave Act. ${ }^{93}$ Reporting back to the Liberator in July I 85 I, William Wells Brown, one of the few fugitives to achieve a significant degree of financial autonomy, noted that "already hundreds have landed on these shores; every week shows an increase in the number of fugitive slaves in London." Brown issued a stark warning, however: "I would say to our fugitive brethren, if you don't want to become beggars, don't come to England." 94

Each of the pathways charted here was one avenue of the United States' continued interdependence with the Atlantic world. Antebellum Americans journeyed, lived, and worked abroad more often than their colonial forebears. Over the antebellum period, transatlantic travel costs and times shrank, swelling the volume of transatlantic traffic. "Time and distance must submit to comparative annihilation," declared one leading American periodical in I $849 .{ }^{95}$ These transformations also helped to integrate further the transatlantic cultural, social, and economic networks participated in by travelers and migrants. The most extensive and resilient webs of connection were those created by American merchants in Britain. Emigrant merchants lived and worked overseas for long periods of time, collaborating closely with British merchants and financiers and with their partners in the United States to ensure the reliability of long-distance trade. At the same time as building their businesses, emigrant merchants worked hard to create and maintain trading routes, to keep open the flows of knowledge and credit across the Atlantic, and to establish strong social connections with fellow traders and elite Britons. But this integration was double-edged: for many Americans Atlantic interdependence was evidence of the United States' ongoing colonial dependence.

\section{THE COMMUNITY OF TRADE}

Writing home from London in $\mathrm{I}_{7} 85$, Abigail Adams complained to her son, the future president John Quincy Adams, that "our countrymen 
have most essentially injured themselves by running here in shoals after the peace, and obtaining a credit which they cannot support." Seeking to restore American trade and revive its lost prosperity, American merchants had instead "shackld and hamperd [sic] themselves." ${ }^{96}$ American merchants bound the United States in a transatlantic world of goods and credit that raised the specter of colonial dependence to US citizens every day through the material objects they handled, encountered, and desired. ${ }^{97}$ Political independence seemed only to reaffirm the new nation's continued economic dependence. As one enraged Virginian wrote in I787, "All is British! British customs, British manners, British dress, British fashions, British folly and British vice." 98 Contentious as they were, colonial patterns of trade persisted long after the Revolution. "Though emancipated from foreign political domination," complained one mid-century author, "the people seemed yet enchained in complete dependence upon the workshops of Europe." 99

For American merchants, the best way to restore transatlantic trade and outmaneuver their Dutch and French rivals was to follow old passages of travel across the Atlantic. After the war, few Americans doubted the importance of commerce to the survival of the republic and hoped to "lead the world into a revolution in free trade" in which Britain would be one of many trading partners. ${ }^{100}$ Yet, although American exporters travelled to a wider range of European ports than before the Revolution, Britain remained the United States' largest export market, its greatest creditor, the largest re-exporter of American goods, and the chief exporter of factors of production (labor, capital, and technical expertise) to the United States. ${ }^{101}$ The early republic's merchants therefore worked ceaselessly to re-open, and then keep open, colonial patterns of direct trade with Great Britain and to maintain the social networks of Atlantic commerce-though their ability to rise above their own interests in the marketplace was doubted. The proper extent of merchants' role in securing the new nation's independence was contested by agrarian theorists and proponents of a national system of manufactures alike. ${ }^{102}$ "For an independent nation, to depend wholly on the supply of others, for their clothing and every other manufacture, is quite a political solecism," wrote one economic nationalist in 1785 ; "such a people may please themselves with sounds, and their independence like a child's rattle, may tickle their fancy." 103

But British goods did tickle the fancy of American consumers. Despite the readjustments of the Confederation Period, trade boomed in the British Atlantic. In 1784, imports of British goods to the United States 
totaled $£_{3} .6$ million, the highest amount since I77 I. $^{104}$ At the close of the Revolutionary War, American merchants rushed to restore prewar connections and mend the disrepair of Atlantic trade, and a new generation of "transatlantics all young and unknown" entered London's merchant community. ${ }^{105}$ According to Connecticut merchant Silas Deane, writing in April $\mathrm{I}_{78}$, American merchants poured into Britain "from every quarter of their late dispersions" and went "as far as their money or credit [would] carry them in the purchase of goods" to ship back to the former colonies. ${ }^{106}$ Observers at the Bank of England noted that "very few of the parties who represent the American houses in our market can be looked upon as permanent residents because they are constantly changing." ${ }^{107}$ As a result, trust and credit-worthiness had to be continually reestablished. Among the new "transatlantics" was the eldest son of Robert Beverley, a Virginian tobacco and wheat merchant, sent to cultivate new contacts at the close of the war. He was not alone: many American merchants, including Thomas Blount and John Hatley Norton, travelled to the capital hoping to establish social standing and lines of credit from investors at the Royal Exchange. ${ }^{108}$ William Bingham, a Philadelphian merchant and privateer made rich by trade in the French West Indies, took up residence in London between $\mathrm{I}_{7} 83$ and I 786 to rebuild his family's commercial connections with Baring Brothers bank. To do so he arranged lucrative marriages between the two families, merging their business interests in the process. ${ }^{109}$

Slowly, these commercial emissaries reestablished confidence in the Atlantic world's trading networks by restoring personal relations (established by marriage and religion) that extended back into the colonial period. ${ }^{110}$ Freed from Alien's Duty, the total exports from the United States to Great Britain were 37 percent above their prewar level by the early I790s. ${ }^{111}$ By I790, Britain received as much as half of the United States' exports, and the United States took four-fifths of its imports from Britain. ${ }^{112}$ Disillusioned that the Revolution had not created a new world of free trade, James Madison complained as the First Congress met in May I789 that Great Britain "has bound us in commercial manacles, and very nearly defeated the object of our independence." 113 Meanwhile, Federalist political economists, dismissed as "Anglomen" by their opponents, attempted to restore the United States' public credit and fund the national debt (then more than thirty times greater than the federal government's expected annual income) through a national bank and the mobilization of mercantile capital, all of which required close 
commercial ties to Britain and the City of London. ${ }^{114}$ Bitter disputes over fiscal and foreign policy soon convulsed the Union.

For all the ferment at home, the United States' trade fared surprisingly well throughout the repeated international crises that began with the French Revolution in I793. Between I792 and I795, customs duties collected in the four major ports of New York, Philadelphia, Baltimore, and Charleston totaled \$I 8.I million, compared to just \$I.2 million in internal revenue. ${ }^{115}$ I 795 brought the Jay Treaty, which guaranteed the "neutral rights" of American shipping, granted trade between the United States and Britain "most favored nation" status, reopened British ports to American merchants, and also opened a limited number of imperial markets. Propelled by the treaty's provisions, the export trade of the United States surpassed $\$ 90$ million by I 80 г. ${ }^{116}$ While the Embargo and the War of I8I 2 all but destroyed the nation's overseas commerce, it recovered dramatically after I 8 I 5 , sped by European demand for grain and the quickening pace of British industrialization after the Napoleonic wars, only to stall once more with the Panic of I8I9 and the ensuing depression that lasted until г 82 г.${ }^{117}$ Even Madison, who had warned of the Anglicizing impact of British trade more than twenty years earlier, mused in I 823 that the United States' continued dependence on Great Britain provided both prosperity and protection: "With the British fleets and fiscal resources associated with our own we should be safe against the rest of the World." 118

Throughout this period of turbulence, emigrant merchants tried to build their businesses. Liverpool emerged as the emporium of Atlantic trade in the years after the Revolution. Visiting the city in I 800, Pennsylvanian paper manufacturer Joshua Gilpin recorded ten prominent American houses in the port-a number that continued to rise alongside the city's stature as the gateway to the British Empire. ${ }^{119}$ At the time of Gilpin's visit, Liverpool was still a minor city, surpassed in population by more than forty other urban centers on the continent, but in the following four decades its population quintupled and the city became the sixth largest in Europe and the third largest in the Atlantic basin. ${ }^{120}$ Residence in Liverpool was a necessity if merchants were to overcome the basic challenges of overseas trade-long delays in communication, vulnerability to market fluctuations, and the difficulty of attracting credit-that remained constant between the colonial and antebellum periods. In real terms, importer and exporter could be weeks apart, and an experienced go-between was vital. As one guide to business etiquette informed its 
readers, the merchant "can scarcely move without danger. He is beset on all sides with disappointments, with fluctuations in the current of business, which sometimes leaves him stranded on an unknown bar, and sometimes sweep him helpless into the ocean." ${ }^{121}$ As the Southern Cultivator put it, merchants lived a life of "abject slavery" in which they were "dependent on their credit, dependent on the banks, dependent on their customers, dependent on their friends." 122 Although the invention of packet ships in I 8 I 8 regularized sailing schedules and the Cunard Line's Royal Mail steamship franchise of I 840 increased the speed and regularity of mail delivery, the exchange of information did not accelerate dramatically until the successful laying of the Atlantic telegraph in I866. Until then, to expand the reach of their operations and maintain flows of accurate information between marketplaces, merchants established webs of interlocking partnerships between ports. ${ }^{123}$

Residence in Britain also meant closer proximity to a wider variety of stock. This was the case for the Boston-based brothers Nathan and Eben Appleton, who entered into partnership with Daniel E. Parker in I8 8 Io. Explicitly writing into the deed of partnership that it was "for the interests of the concern that one or more parties should reside in England," Eben departed for Liverpool within the next year. ${ }^{124}$ Once in the port, Eben travelled through the manufacturing districts of West Yorkshire purchasing goods direct from the manufacturer, cutting out costly commission agents. "By going into Yorkshire I think you get the goods very low and very soon," Nathan wrote Eben, adding that "low priced woolens are at present in great demand \& must be higher in the winter." 125 The American dry goods importers John Guest \& Co. alighted on the same solution. While the firm's co-partners lived in Liverpool and Philadelphia, they also employed George Palmer, a native of Philadelphia, who described to one Parliamentary committee his role as a purchasing agent of finished wool and dyed cottons from Yorkshire textile mills, which enabled the firm to forgo costly commission merchants. ${ }^{126}$

With success dependent on merchant houses' reliance on trust and personal character, family and co-religious networks were central to international trade. ${ }^{127}$ The wholesale grocer Daniel James rose rapidly through the merchant ranks thanks to the web of family contacts, partnership agreements, and business strategy that defined the careers of many transatlantic merchants. ${ }^{128}$ In I 829, James married Elizabeth Woodridge Phelps, daughter of the wealthy New York merchant Anson Greene Phelps. Two years later, James replaced his father-in-law's existing partner in Liverpool, Elisha Peck, who wished to return to the United States after fifteen years 
on Merseyside. At the same time, Phelps entered into a second partnership with another son-in-law, William E. Dodge, to form Phelps, Dodge \& Co., which operated from New York. Dodge imported tin plate, sheet iron, copper, and other metals through the Liverpool house, which in return received cotton from New Orleans and, soon, from the firm's regular packet ship between Liverpool and Charleston.

The two linked firms thus became some of the most prominent importer-exporters of cotton and metals in both countries, but their transatlantic partnership required constant attention to succeed. From Liverpool, James maintained a ceaseless vigil over the flow of transatlantic communication. "I am now without any of your favours to reply to \& sometimes think you must be sick with my long epistling," James chided Dodge early in the partnership, "but I am fully of opinion [sic] that the interest of the business is greatly profited by a free and full communication \& exchange of our opinions on these matters." ${ }^{129}$ Regular contact helped to clarify market uncertainties, ease decision-making, and facilitate longterm planning-especially important at times of financial crisis, which soon hit the firm. "I want exceedingly to know what are taken up and what are not," James wrote Dodge from Liverpool at the height of the Panic of I 837 , since "next month I am going to see all the manufacturers \& this information if I had it would do us much good." 130 As long as transatlantic communication remained dependent on prevailing winds, regular correspondence detailing stock inventory, accounts, and analyzing local market information was highly valued.

Because merchants put great faith in trustworthy correspondents thousands of miles away to supply them with accurate information, their letters were replete with the language of "confidence." 131 James, for instance, underlined the veracity of intelligence and gossip with phrases like "all this Shipley told Banks in entire confidence," "Browns has always made confidant of Banks," and passed information to his partner, "in confidence and to you only." 132 Before the invention of credit-reporting agencies, merchant elites prized intelligence on personal character to generate confidence. ${ }^{133}$ When James Brown, of the New York-based Brown, Brothers \& Co., described Robert White to Joseph Shipley, his partner in Liverpool, as a "very bad tempered man and ... too selfish," he was not engaging in idle gossip but sending a clear indication: White was not credit-worthy. ${ }^{134}$ Confidence possessed the power to generate credit-and with it, risk. Confidence could itself be generated through the public demonstration of gentility and social status, key pursuits of the gentlemanly merchant-bankers explored in 
the next chapter. Character and reputation, then, were powerful cultural forces underlying the expanding, credit-dependent, and therefore risk-laden, transatlantic economy.

For traders, emigration brought an apprenticeship in the day-to-day practicalities of international commerce that the theorists of political economy could not. In July I 843, William E. Bowen wrote from the Philadelphia branch house of Brown Brothers that their former agent in the Gulf Coast cotton port of Mobile, George Cleveland, was on his way to Liverpool. Once there, Bowen wrote, "he will have an opportunity of learning how things are done on your side and will come back well posted up." In his letter of introduction to Shipley, Bowen included key details about Cleveland's character, noting that he was "a very honest fellow, though his first appearance may not strike you as prepossessing" and that he "devotes his best energies and services to promote our interests." ${ }^{135}$ Cleveland followed in the footsteps of many leading US merchants who cut their commercial teeth in the counting houses of London and Liverpool before returning to the United States. Pursuing a commercial apprenticeship overseas could be a shrewd business decision, granting access to new areas of expertise, new lines of business, and additional sources of capital. As a result, it continued throughout the antebellum period and was integral to the professional identity of many merchants in the Atlantic world.

Merchants worked hard to create and strengthen the institutions sustaining Anglo-American trade. In Liverpool, the Exchange was among the most important of these institutions. Opened in 1754 as an expression of the port city's commercial self-confidence, the "change" was a place where Liverpool-based merchants and agents met to buy and sell goods, establish credit-worthiness, and cultivate social contacts. As the port's importance grew, its merchants formed the Liverpool Chamber of Commerce in $\mathrm{I} 774$ as a political pressure group where prominent merchants coordinated their response to political crises. More informal, non-market centered spaces that were part business association, part social club such as the City Tavern, Pontack's Coffee House, and the Merchant's Coffee House, were arenas of business activity and spaces to measure the social standing of potential customers. ${ }^{136}$

As specialist trades and commodity markets multiplied, and the allpurpose trader who dominated the eighteenth century declined, so did the formal lobbies that provided advice and information for their members. The associations in Liverpool were organized around the port's expanding global interests, and included the African Committee (I777), West 


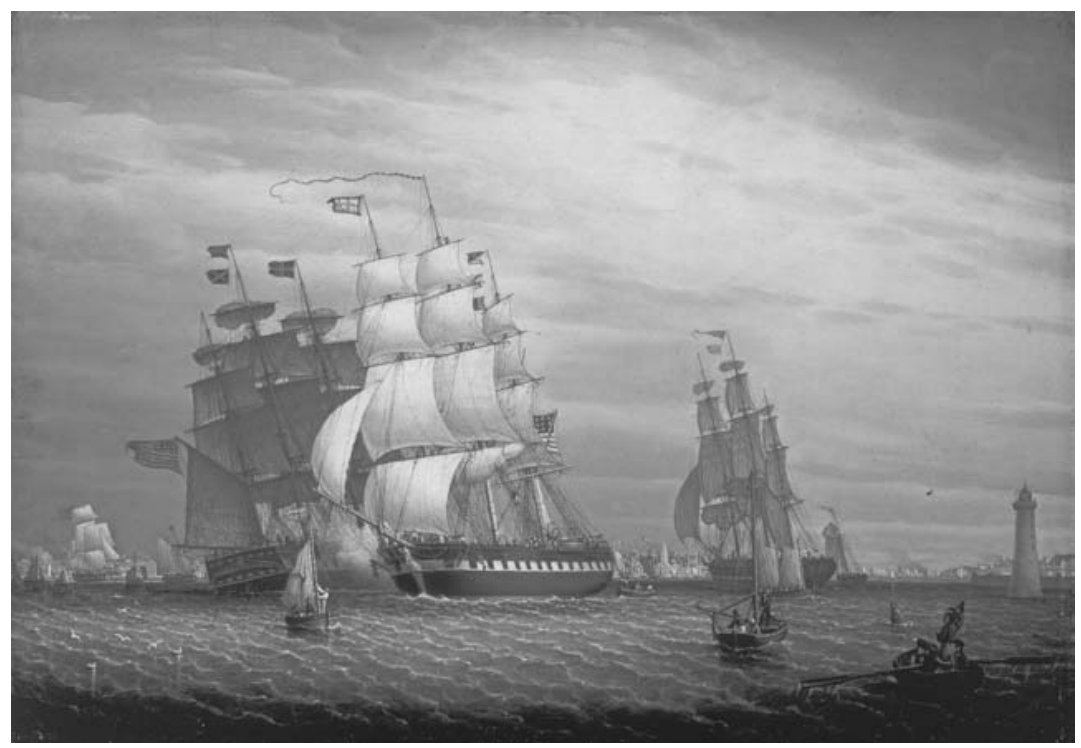

FIGURE 6. Robert Salmon (I775-I 845) painted more than one thousand maritime and seascapes in his career. Fittingly, he enjoyed a transatlantic career: in I 828 he migrated to Boston, where he thrived accepting commissions to paint ship portraits and harbor views. Here, a pair of American ships approach the Liverpool docks, obscured by a mass of flags and sails on the choppy waters of the Mersey. Image: Robert W. Salmon, American Ships in the Mersey, oil on canvas, I8 I I, courtesy National Museums Liverpool.

Indian Association (I799), and East India Association (I 8 I 8), indicating the port's early integration into global markets. ${ }^{137}$ Specialist lobbies for particular products developed later, such as the Cotton Brokers' Association in I84I and the Corn Trade Association in I853, and indicated the rise of American interests in the port (see figure 6). Such trade associations were mechanisms of network management, "absolutely necessary" to coordinating international trade in the assessment of one observer, a task that was "beyond the power of individuals." 138 Their members maintained "watch" or "superintendence" over the port's trade, gathered reliable information, and lobbied local authorities to improve the infrastructure of international trade. ${ }^{139}$ These commercial associations, wrote the British journalist Thomas Baines, were "the public face of business," and because their trading networks were so stretched across time and space, merchants paid close attention to their operation. ${ }^{140}$

To support the growing volume of transatlantic trade, American merchants in Liverpool established the American Chamber of Commerce 
(ACC), a cosmopolitan body drawn from the port's international merchant diaspora engaged in the American trade. Founded in July I $80 \mathrm{O}$ at the instigation of the US Consul at Liverpool and Virginian tobacco merchant, James Maury, the ACC aimed at "the redress of existing and prevention of future grievances" afflicting the North American trade. ${ }^{141}$ The ACC was committed to maintaining Atlantic trade. "It takes cognizance of all questions affecting the American trade," reported one newspaper, adding that it had been "instrumental in effecting improvements of the mercantile law of this country." ${ }^{142}$ Locally, the Chamber liaised with the Liverpool dock management to plan the expansion of harbor and warehousing facilities and the port's connections to canal and railway infrastructure. Nationally, it lobbied Parliament and the Board of Trade through petitioning and the energetic work of John Backhouse from its London office. ${ }^{143}$ Between its founding in I $80 \mathrm{I}$ and the end of the US Civil War, just seven of the ACC's presidents were American citizens, with a similar number being drawn from the ranks of German and French traders. ${ }^{144}$

The Chamber also fulfilled important social functions essential to the smooth operation of long-distance trade. Just as many of London and Bristol's pre-revolutionary coffee houses acted as a "lifeline to America" for anxious colonists, the ACC enabled Americans in the city to preserve national connections through the exchange of news and gossip, and the reception of visitors. ${ }^{145}$ The Chamber's committee acted as a delegation when new American consuls and ministers arrived in the port, extending hospitality in its role as diplomatic lobby. ${ }^{146}$ In April I 842, the ACC also created a reading room where itinerant and resident Americans could find British and American newspapers along with Parliamentary, Congressional, and statistical papers. ${ }^{147}$ In this respect, the ACC reflected the constant interplay between integrating with local professional and social customs and the creation of distinct national institutions and spaces that characterized the lives of many American migrants.

Atlantic traders operated in a series of overlapping national, international, and global social and professional networks. Transnational merchants traveled freely between distant cities and towns, corresponded regularly with like-minded people, and at times lived overseas for long periods of time. ${ }^{148}$ American migrants in Britain were not exceptional in this respect. In the United States' major Atlantic ports, just as in European ports, British and European merchants established branch houses to coordinate trade and investment, reflecting a broader exchange of merchant talent between international ports. ${ }^{149}$ The merchant and 
brokerage houses crowding Wall Street and Pearl Street in Lower Manhattan swelled with Britons and Europeans attracted by the variety of imports and exports landing at the wharves. ${ }^{150}$ By the I 830 s, Britishbased banks viewed the United States as an attractive longterm investment and provided direct investment in American firms expanding cotton and lumber production and constructing canal, turnpikes, and railways in the United States, in addition to underwriting the bond issues of states undertaking their own infrastructure projects. ${ }^{151}$ Maintaining this complex financial network required careful, conscious efforts at collective organization. Major transatlantic markets did not emerge naturally, but were coordinated by the human infrastructure of overseas correspondents, agents, and go-betweens. In the words of one contemporary assessment, migration to Britain placed these individuals "at the very heart of a world-wide commerce-beholding and understanding the multiplied and intimate connections on which the vast interests of commercial credit and prosperity depend." ${ }^{152}$

But just as contemporaries recognized that transatlantic merchant and financial networks generated great wealth and prosperity, they were also anxious about exposure to the powerful economic headwinds that accompanied interdependence. As financial panic gripped the American economy in I 837, and no fewer than eight states and the territory of Florida defaulted on their debt, transatlantic merchants came under attack for their abuse of paper credit and disregard of the national interest. Anglophobic Democrats argued that merchants' international connections were an integral element of the "entangling alliance" between the "banking and mercantile class" and "the colossal money power of Great Britain." 153 The claim that merchants had engaged in "overtrading" and upset the constant struggle to balance the nation's fragile political economy was made repeatedly by the Democratic press. ${ }^{154}$ "The people of the United States will now perceive more fully than could be learned from volumes of elaborate argument," charged the Jacksonian Globe at the height of the crisis, "the necessity of guarding inviolate the public faith, by disengaging the public finances from a groveling state of dependence upon the operations of private mercantile speculations." ${ }^{155}$ As the cousin of Joseph Shipley wrote in an acerbic aside, "By the way, I think the increases of your Bank have greatly aided in producing the present discord by striking the first blow of that confidence which if it had been properly sustained might have enabled them [the American people], if not to ride the whirlwind, at least to have given discretion \& greatly diminished the force of the storm." ${ }^{156}$ 
As the storm receded and the export economy revived, transatlantic merchants could not promise stability but, against familiar charges that they were too interested to make virtuous citizens, insisted they were the agents of American economic independence. Transatlantic merchants were as much economic nationalists as Democratic partisans, but viewed the dense web of social, economic, and cultural connection that knit together the Atlantic world as the surest route to restoring the health of the public finances and securing US independence. Writing to his partner in Liverpool in I843, William Brown reflected that American citizens were "daily learning that we have the material within us which if properly worked up will keep us independent of the Old World." ${ }^{157}$ Later in the decade, Brown told the same correspondent that he "never could doubt as to national feelings. We must agree in being Americans first." Yet, in a measure of the ambivalence felt by many transatlantic merchants, he added that he had "too many ties to dear Old England to blot her out from my affections." 158 The decades between the Panic of I 837 and the onset of the Civil War only brought further degrees of interdependence between the US economy and the financial and commercial instruments of the British Empire. At the center of this new interdependence was the credit-thirsty processes of US state-building and the lucrative cotton trade.

\section{ENTREPÔT OF COTTON, METROPOLIS OF CREDIT}

In I 838, Liverpool's docks stretched an impressive two and a half miles in length and captured some ninety acres of water; twenty years later, they extended over nine and a half miles (see figure 7). ${ }^{159}$ The chaotic port crowded the senses. Bundles of textiles from mills in Lancashire and Yorkshire, Indian calicos and teak, crates of Midlands metalwares, bars of Swedish iron, and dusty bushels of Australian wheat struggled for space on the wharves. The tang of spices from around the world, earthy tobacco from Virginia, and the smoky aroma of lapsang teas from Asia fought against the stink of tar and fish. And over everything, "like an evil spirit," hung a pall of sooty smoke from the steamers and the local soda and glass works. ${ }^{160}$ Visiting Americans gazed in awe at the "bustle" of dockside traffic, the scale of its "towering warehouses," and the "tangled masts and yards" that reached still higher and gave the impression of "large forests destitute of foliage." 161 "The particolored flags of various nations, streaming gaily from the numerous masts," recorded Zachariah Allen, "became mingled together, as in the great race of mercantile 


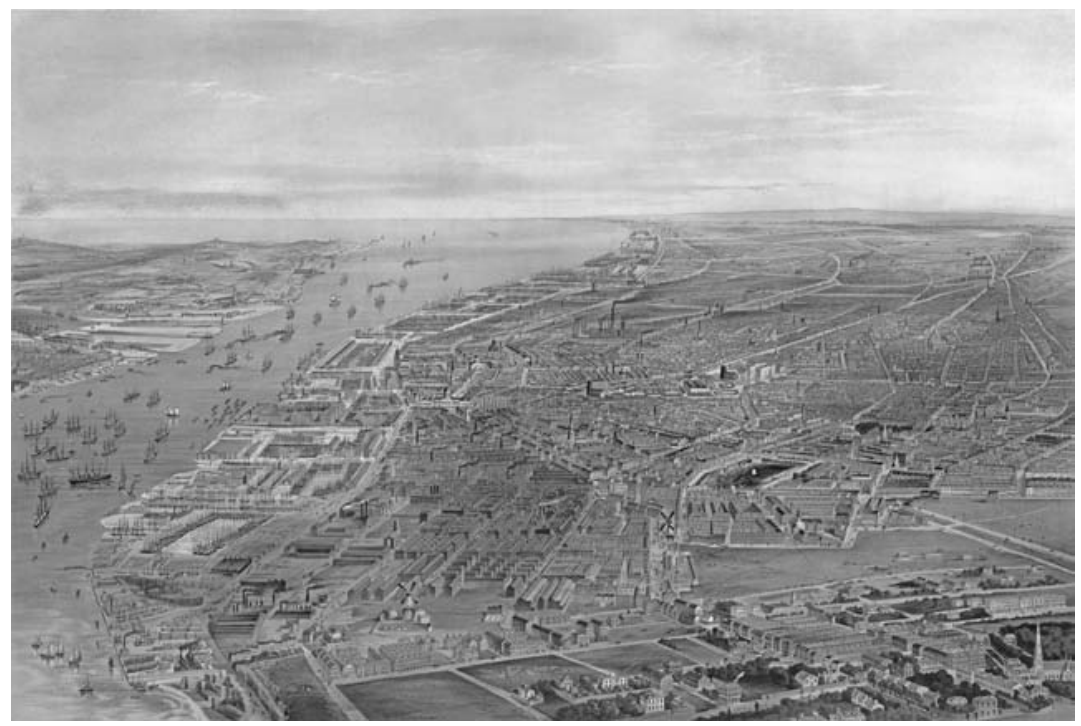

FIGURE 7. The scale of Liverpool's shipping is captured vividly in this panoramic map. Panoramic maps were a popular cartographic form for representing urban centers from above, usually from an oblique angle, so that street patterns, notable buildings, and the drama of urban life could be evocatively portrayed. Such maps, writes Susan Schulten, were "a form of civic promotion that combined art, advertising, and cartography" (Mapping the Nation, I 57). Several panoramic maps of Liverpool were produced in the nineteenth century, including Ackerman's Panoramic View of Liverpool (I847) and the colossal Illustrated London News's "View of Liverpool from the Mersey" (I 865). (Both maps can be found in excellent quality and detail at https://historic-liverpool.co.uk/ old-maps-of-liverpool.) Image: John Raphael Isaac and Vincent Brooks, "Liverpool, I 859, Part of Birkenhead, the docks, and Cheshire Coast," Library of Congress Geography and Map Division.

competition." 162 Amidst this throng, the docks themselves stood out as "noble," "magnificent," and "stupendous works," that demonstrated "in a most astonishing degree the power of science and art in overcoming ... insurmountable obstacles." 163 American merchants loaded their ships at Prince's dock alongside the transatlantic packets. Completed in I 82 I, Prince's was the largest dock yet built. A pair of forty-five-foot wide locks guarded more than four hundred and fifty meters of landing space and eleven acres of water (equivalent to ten city blocks) from the Mersey's swells. ${ }^{164}$ Through the eyes of one American tourist, they were the "glory of Liverpool," while to another, "nothing in the world is to be seen more magnificent in extent." 165

After landing and negotiating the crowds of cab drivers and porters in "ragged garb" waiting outside the doors of the Customs House, 


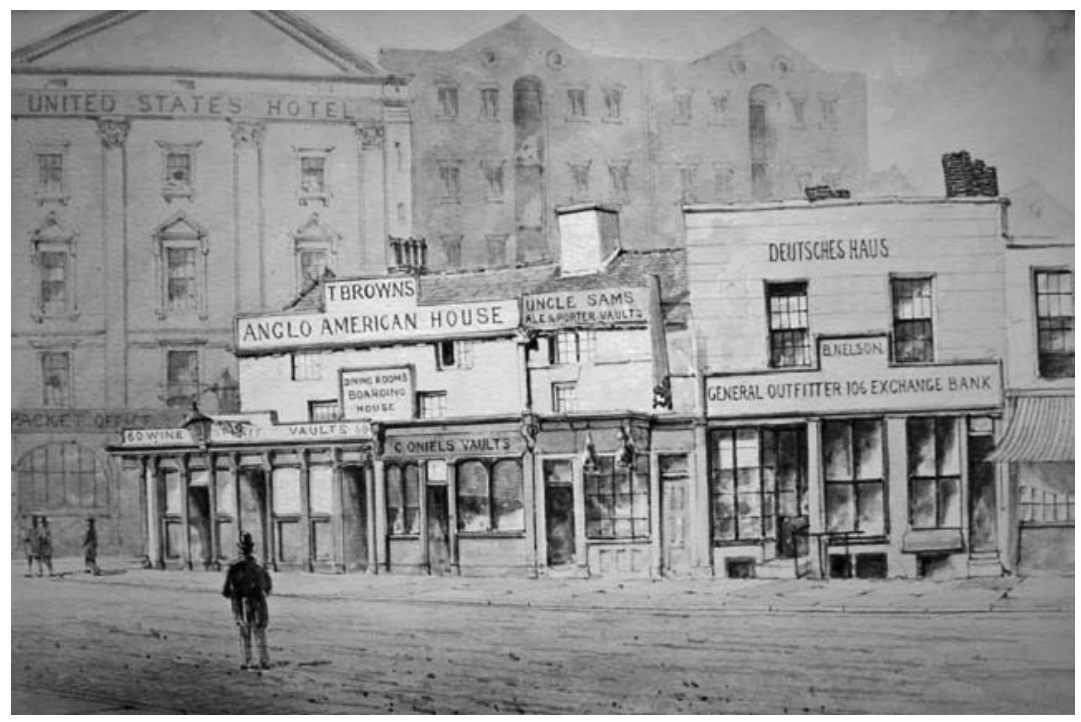

FIGURE 8. In the foreground stands the Anglo-American House, a dining room and boarding house, and Uncle Sam's Ale and Porter Vaults. In the background stands the United States Hotel. Image: William Gawin Herdman, "Waterloo Road, Liverpool, eastern side from Oil Street to Vandries Street," watercolor, I 859, courtesy of Liverpool Record Office, Liverpool Libraries.

American migrants found that the trade in goods and travelers between Liverpool and the United States shaped city spaces. ${ }^{166}$ One of the first ports of call for newly arrived Americans was the US consulate on Paradise Street, which ran along the quayside of Steer's Old Dock. While the personnel changed, the consulate remained a fixed point, providing the services required by a wide cross-section of Americans overseas. For ship captains it was the place to register cargoes, and for travelers and migrants it was a place to read the latest American newspaper or request official documents. Washington Street was home to the United States Hotel and its "parade of American insignia" (see figure 8). Above the door perched an "American Eagle, and the national motto" to which, Silliman reported, Americans crowded "in great numbers" excited by "patriotic sympathy." 167 The offices of Brown, Shipley at 7 Union Court, Castle Street, were the headquarters for American ship captains, where they kept abreast of recent arrivals and market information. ${ }^{168}$ Only a stone's throw from the Liverpool Exchange and Customs House was Mary Blodgett's guest house. Blodgett's was, in the assessment of one resident American, "the favorite resort of American sea captains and shipping men, and ... 
a sort of central point for all Americans in Liverpool." ${ }^{169}$ It was briefly home to Nathaniel Hawthorne, after the celebrated author accepted the position of consul in the city, and also to the two consuls who preceded him, Robert Armstrong and the Kentuckian Thomas L. Crittenden. There was, concluded one writer, "perhaps no other city in England where America is more justly appreciated," where "our commerce fills its docks, and our merchants move in its society." 170

Liverpool's American merchants not only moved in society, but shaped the port's priorities. In 1780 , Liverpool imported no cotton whatsoever from North America. By I 833-once American slavery had taken command of cotton production-the port had captured 90 percent of the global trade, twenty times the amount landed in London. ${ }^{171}$ With the arrival of power weaving after I 830 and the expansion into and conversion of the fertile lands of the Mississippi River valley to cotton production, cotton exports boomed. While in I830 the United States' cotton exports totaled almost \$27 million (4I percent of total US exports), by I 860 that figure had risen to almost \$I 92 million ( 58 percent of the total). ${ }^{172}$ The bags of "white gold" landed on Liverpool's wharves connected mill towns in Massachusetts and Lancashire more than three thousand miles and twenty-eight days' sail away; linked more than four million slave laborers with between one-fifth and onequarter of British laborers; and enmeshed ports up and down the United States' Atlantic seaboard with Europe and onward to markets in Asia. For slaveholders and slavery's bankers in the American South, in the words of New York journalist Thomas Kettell, cotton "enveloped the commercial world, and bound the fortunes of American slaves so firmly to human progress, that civilization may be said to depend on the continual servitude of blacks in America." 173

Cotton has become the preeminent global commodity for historians of nineteenth-century global capitalism, consumption, and the South's transnational connections alike. ${ }^{174}$ The best of the new literature on cotton's centrality to global capitalism, by Brian Schoen, Sven Beckert, and Giorgio Riello, places the institutional structures of trade created by merchants at the center of analysis. ${ }^{175}$ Beginning in the mid-eighteenth century, a new regime of consumption centered on cotton propelled a global realignment of agricultural labor regimes and a relocation of cotton production from Asia to Europe and the Americas. ${ }^{176}$ Liverpool's eighteenth-century merchants enriched themselves both by trading in slaves and taking advantage of the port's close relationship with its industrial hinterland. ${ }^{177}$ The textile industries of South Lancashire provided a large market for imported 
Northern cereals and slave-grown staples, and Liverpool merchants established strong business alliances with Manchester textile merchants and financiers in London. As we saw in the previous section, the webs of credit, social connection, and trust at the heart of the cotton trade did not appear naturally. Instead, they relied on the business acuity of a vast network of skilled merchants for their economic vitality. ${ }^{178}$

Cotton's connective power created a mutually beneficial interdependence for those engaged in its transatlantic trade. ${ }^{179}$ For Southern planters and factors, the ever-expanding British Empire would be the best means of extending the South's reach into global markets, but the cottoncarrying trade was equally lucrative to Northeastern bankers, merchants, and shippers. Most cotton arrived in Liverpool on ships from the Northeast, which by the mid-I 820 s carried 90 percent of the United States' total export trade. ${ }^{180}$ Northern carriers rode trade winds that carried them on a triangular route between southern ports and Liverpool before they returned home to Northeastern ports laden with finished European manufactures. ${ }^{181}$ The majority of Americans in the port were drawn from the merchant elites of New York, Philadelphia, and New England, who dominated the transatlantic carrying trade or ran the financial institutions servicing the cotton trade. ${ }^{182}$ Specialist Liverpool-American merchants and brokers were twinned with London-American financiers and together constituted the principal conduits of the Atlantic economy.

The cross-sectional nature of the cotton trade cautions historians against the easy assumption that the port would naturally have been a stronghold of Confederate support. Despite Liverpool's centrality to the Atlantic slave trade before $\mathrm{I} 807$ and the subsequent predominance of the American cotton trade, Liverpool-Americans' identification with the southern states was deeply ambivalent. Few Southerners engaged in the cotton trade resided in the port until the opening of the cotton broker Fraser Trenholm in I 856. In the decades before Fraser Trenholm's arrival, Southern interests failed to coalesce around the trade associations of the city, with an important consequence: Southerners were less well-connected in Britain than were Northerners engaged in trade and finance. Although one traveler complained early in the century that Liverpool's merchants "pray God, not to change the colour of the negroes," the port was, after all, the birthplace of the abolitionist George Thompson. ${ }^{183}$ Many of the ACC's most prominent Quaker members were intimately connected with Liverpool's abolition movement. James Cropper, for instance, a founding signatory of the ACC, was president of the Liverpool Anti-Slavery Society and closely tied to the transatlantic 
anti-slavery network, even working alongside fugitive slaves and free blacks to discredit colonization schemes among the British public. ${ }^{184}$

Connections between Liverpool and the capital integrated the financial services of the City of London with the specialized markets of the Liverpool quayside, especially after the completion of the London and Northwestern Railway in I846. Proximity to the hubs of information, contacts, associations, and capital of both cities prompted the formation of American communities. Liverpool was not simply the economic satellite of London, however. The process of economic integration was multidirectional. Established banking firms such as Kleinworts, Rothschilds, Barings, and Brown, Shipley grew rapidly in this period, consolidating their position as major transatlantic merchant banks. These firms relied on up-to-date intelligence about commodity markets in Liverpool and appointed a network of agents to maintain the stream of information. ${ }^{185}$

So lucrative was the cotton trade that some Liverpool merchants made the transition from trader to financier. The Baltimore-based W. \& J. Brown \& Co. opened their Liverpool branch in I8Io, quickly establishing a foothold in Liverpool's merchant community as the port's premier cotton traders. ${ }^{186}$ In I 825 , William Brown joined with fellow Liverpool resident Joseph Shipley, of Delaware, who was the agent of the Philadelphian merchant John Welsh, to create Brown, Shipley \& Co. While the Liverpool house continued handling cotton consignments in concert with the firm's Southern branches, the partners sought protection from the volatility of Atlantic markets and state debt defaults by the mid-I83os. Brown, Shipley, operating long-distance with James Brown at the New York branch, began to concentrate on the provision of financial services. ${ }^{187}$ William offered numerous small lines of credit, according to the Bank of England's agent in Liverpool, "to different agents of American houses who travel through the manufacturing districts and order goods at Manchester, Birmingham, Sheffield and other places." 188 In doing so the firm connected its branches in Baltimore, Philadelphia, New York, and Liverpool with its agents in Mobile, Natchez, New Orleans, Charleston, and by 1849 San Francisco, creating an international trading network that connected the markets of the American continent to the commercial and financial emporiums of the British Empire.

More established English banking houses moved into the financing of American trade and securities by employing US expertise. Baring Brothers extended their interest in transatlantic finance by opening a Liverpool office in I832, appointing the American Samuel S. Gair and the Briton Charles Baring Young as partners in the port. ${ }^{189}$ The Liverpool branch 
was one point on a network connecting London, Liverpool, and Boston via Barings's investment capital, masterminded in part by Joshua Bates. Born in Weymouth, Massachusetts, Bates arrived in England in I8I6 as the European agent of the Bostonian merchant William Gray, specializing in the Russian and Indian trades. ${ }^{190}$ The New Englander successfully cultivated contacts with prominent merchants in London, from which he built a firm with John Baring in I 826. Soon after, the firm, with its client list of nearly three dozen firms trading in the East Indies and Far East including the Bostonian China house Bryant \& Sturgis, was bought out by Baring Brothers. ${ }^{191}$ The move placed Bates at the center of AngloAmerican finance and was the most productive partnership between a British bank and American state-building. The British bank was partially responsible for doubling the size of the United States in $\mathrm{I} 8 \mathrm{O}_{3}$ by negotiating the Louisiana Purchase, and was subsequently appointed the United States' agent in London- “Jefferson's Empire" was made possible by the Federalist system of international high finance. After the War of I8I 2, Barings went on to finance state loans, American railroad building, and the United States' war against Mexico. Bates was made a senior partner after Alexander Baring's retirement in I $830 .{ }^{192}$ The firm's American presence was cemented in I 85 I after Russell Sturgis, another Bostonian, was promoted to senior partner. Convinced that "American business will be safer than any other and should be cultivated with the greatest care," Bates kept abreast of transatlantic political and economic conditions via these vast networks of familial and business correspondents. ${ }^{193}$

The chief rival to Bates's pre-eminence on the American securities market was another New England financier, George Peabody. The third-born of a family of eight siblings from South Danvers, Massachusetts, Peabody cut his commercial teeth as a dry goods merchant in the firm Riggs, Peabody, \& Co., operating from Baltimore. Between I 827 and I 837, Peabody made several successful trips across the Atlantic on behalf of the firm, before establishing George Peabody \& Co. amid financial panic in the Atlantic world. Taking advantage of the availability of funds in London, Peabody specialized in American state bonds before moving into the world of Anglo-American stock and commodity trading. ${ }^{194}$ By mid-century, Peabody financed everything from American securities to railroad iron exports and the silk trade in China, amassing a \$20 million fortune in the process. ${ }^{195}$ Peabody took on the New Yorker Junius Spencer Morgan as his partner in I 854 . Residence in Britain was a necessity for American financiers seeking proximity to London's global financial instruments and was key to the favorable conditions 
enjoyed by the United States within Britain's international financial system. ${ }^{196}$ American emigrants were partners in major transatlantic banks, managed their branches in commercial hubs in Britain, and developed strong connections with British political and economic elites in London society (the subject of the next chapter).

As a result, after independence a consistent flow of British capital crossed the Atlantic and London became a bull market for US Treasury bonds, state and national debt, and American railroad securities. ${ }^{197}$ By I 853 , half of the United States' national debt was held abroad-nearly all of it in the hands of British investors. ${ }^{198}$ Although the New York Stock Exchange was created in I 8 I7, local capital markets were unable to sustain the United States' thirst for development capital. As a result, the republic's transatlantic financial connections deepened throughout the nineteenth century, as the City of London maintained an ongoing commitment to nation-building in the United States. In the estimate of economic historians Davis and Cull, by I 860 Britain accounted for nine of every ten dollars of foreign investment in the United States. ${ }^{199}$

Not only elite merchant bankers were attracted to London's global financial markets, as the biographies of a number of entrepreneurs and inventors in the capital bear out. New York-born Benjamin Franklin Babcock ran B. F. Babcock \& Co., a branch of the Great Western Insurance Company, and naturalized as a British subject in I857. Curtis Miranda Lampson, of New Haven, Vermont, arrived in London in I 830 as an agent of John Jacob Astor, before opening his own fur trading firm, C.M. Lampson \& Co. On May I4, I849, he was likewise naturalized a British subject. In I 856, Lampson was elected to the board of directors of the Atlantic Telegraph Co., and was later created a baronet. Similarly, after serving as the American commissioner to the Great Exhibition in I 85 I, Nathaniel S. Dodge settled in London in I 852 , hoping to capitalize on the imperial market opportunities for vulcanized rubber. Jacob Perkins and his eldest son Ebenezer, engravers from Old Newburyport, Massachusetts, moved to London in I8I9 in pursuit of a contract to print and engrave the banknotes of the Bank of England. These individuals are emblematic of the migration of enterprise that underwrote the Atlantic economy and the way in which migrants were the central actors in the construction of transatlantic interdependence.

Anglo-American interdependence centered on London's inner city of high finance. George Peabody \& Co. stood at the heart of the City of London at 22 Old Broad Street-just a short walk from the Royal Exchange, nestled between Threadneedle Street and Cornhill. The Exchange's Hall of 
Commerce was the center for trading in American railroad securities and was gripped by "Railroad mania" in the mid-I 84 os. It was here, observed the Massachusetts Congressman Benjamin Gorham, that "the barometer of the American money market hangs up." 200 Opposite the Exchange was the Bank of England, the offices of Britain's so-called "money power," to which many Americans traced all manner of domestic and foreign crises. ${ }^{201}$ Next door to the Bank was the former New England Coffee House. In I 825 the Colonial Coffee House expanded into the premises next door and rebranded itself as the North and South American Coffee House, described by one contemporary as "the complete center for American intelligence." 202 Barings, and the office of Joshua Bates, stood just around the corner at 8 Bishopsgate. As Edward Everett described the work of emigrant financiers in the City of London, they were "all concerned in weaving the mighty network of mutually beneficial exchanges which enwraps the world."203 No more than a square mile in size, this was the financial heart of the British Empire, the capital of American credit, and a principal workplace of American emigrants.

The American merchants, financiers, and agents who migrated to Britain worked within formerly colonial frameworks of commercial interconnection. Americans in Britain directed these links, reorienting them as the Atlantic world itself changed, but also reinforced the interdependence of the two transatlantic economies. ${ }^{204}$ As interpreted by transatlantic financiers, these interconnections demanded the temporary co-option of British economic power. It was at this juncture in transatlantic economics that the function of American communities in Britain intersected with disputes over Atlantic political economy in the United States. In an era of rising nationalism, some, particularly amongst the New England Whigs where links with Britain's American community were strongest, argued that meaningful independence could only be achieved by a temporary collaboration with British capital. ${ }^{205}$ Britain's American community was the social context in which this collaboration was rooted.

As American communities in Britain mediated commercial relations between Great Britain and the United States, they performed analogous social functions. In the chapter that follows, John Bull looms large in debates over American national character. Transatlantic cultural ties ran deep, but renewed fears of colonial dependency. As American nationalism and sectionalism at home became both more proscriptive and increasingly assertive, Americans in Britain participated in the clash between Anglophobia and Anglophilia from the "frontline." While 
resident in Britain, Americans engaged directly and immediately with the tensions of American nationalism in ways that ordinary Americans could not. American travelers and visitors attached their own meanings to the patriotic orations of Americans overseas and to the transatlantic relationship. Britain's American community found its national expression contested by partisan and sectional opponents, whose recourse to Anglophobia was swift and voluble. The processes of "unbecoming British" and becoming American did not give way seamlessly to one another. Instead, Americans grappled continuously with the challenge of reconciling fundamentally opposing aspirations: between independence and interdependence, between the desire to beat and to be like their former imperial parent, and between integrating with and remaining distinct from Britain's global commercial system. Nowhere was this more visible than in the social world of Britain's American emigrant community. 